\title{
THE IMPORTANCE OF WRITING AS A METHOD OF CREATING IDENTITY IN FEMINIST CHICANA LITERATURE: TERRI DE LA PEÑA'S MARGINS
}

\author{
Amalia Ibarrarán Bigalondo. Universidad del País Vasco
}

\begin{abstract}
The stronghold of the struggle of the Chicana, in general, as well as that of the Chicana writer in particular, has been that of eradicating all the prejudices which have misdescribed them as compliant women. Stereotypes had been created and sustained by their male counterparts throughout the years, becoming instrumental in the assimilation and "passive" acceptance by the Chicanas of these deleterious preconceived ideas.

The Chicana lesbian writer Terri de la Peña has endeavoured to abolish all the prejudices that had constrained the existence of the Chicanas in general, and that of the Chicana lesbians in particular, as well as the taboos they had been forced to assimilate and transmit. By means of writing, Verónica, protagonist of de la Peña's Margins, abandons the "margins" of her story to take a central position in the development of her new life, in which she fights to renegotiate her space within her community as well as to re-educate its members into a more tolerant, integrative understanding of life.
\end{abstract}

The stronghold of the struggle of the Chicana, in general, as well as that of the Chicana writer, who may be well regarded as an overt portrayal of the aforementioned group, in particular, has been that of eradicating all the prejudices which have misdescribed them as submissive, "ready-to-serve-the-man-and-the-community" women. Stereotypes such as "Women are supposed to live stably and provide stability for others" (Henderson, 1995:34), had been created and sustained by their male counterparts throughout the years, becoming instrumental in the assimilation and "passive" acceptance by the Chicanas of these deleterious preconceived ideas. As stated by Carmen Ramos Escandón,

With respect to Chicanas, do we escape myths depicting them as weak, submissive, overtly respectful wives who completely lack initiative and critical intellectual attitudes? Stereotypes of the chicana avoid examining the nature and source of her oppression. (1989: 204) 
As a consequence, the reconstruction and valorisation of their individual, selfdelineated identity, and its subsequent "publication", has occupied the efforts of these women. They have fiercely fought to find and demand their space both within the prevailing North American social order and their own community, too traditional and obsolete in the way of performing male-female relationships.

In an attempt to renegotiate these misconceptions, the Chicana writer found in literature, and in the novel in particular, a valid channel of expression of her new, self-constructed and individual identity. Furthermore, the novel facilitated the idea of the presentation of exemplary characters who experienced distinct circumstantialities and symbolized diverse patterns of behaviour. These were regarded as helpful for the readers, who could find in these type-like characters some kind of analogy with their own reality or needs. Telling and subsequently, reading these characters' stories and vicissitudes created a strong sense of belonging that invoked the idea of community for both the writer and the reader. The acknowledgment through literature, among other means, of the fact that all Chicanas share similar problems and worries, as well as the same position of inferiority within their families and communities in general, leads the way to the emergence of a strong sense of solidarity among them, which will become the catalyst of their first steps towards the demand of a place of their own within their domestic and social spaces. As posited by Yvonne Yarbro-Bejarano:

By delving into this deep core, the Chicana writer finds that the self she seeks to define and love is not merely and individual self, but a collective one. In other words, the power, the permission, the authority to tell stories about herself and other chicanas comes from her cultural, racial/ethnic and linguistic community. This community includes the historical experience of oppression as well as literary tradition. $(1988: 140)$

The Chicana writer frees herself from the colonizing male voice that had transmitted a manipulated vision of her identity, and engages in the process of filling the blank pages of her own story, always silenced and ignored. As a result, the fact of becoming the subject of her own narrations (articulated and structured from her own voice) has given her the strength to chronicle and proclaim her real self, making the general public accept and valorise it, for

She communicates that rupture, documents the struggle. She reinterprets history and, using new symbols, she shapes new myths. She adopts new perspectives toward the darkskinned, women and queers. (Anzaldúa, 1987:82)

The Chicana lesbian writer Terri de la Peña has endeavoured to abolish all the prejudices that had constrained the existence of the Chicanas in general, and that of the Chicana lesbians in particular, as well as the taboos both groups had been forced to assimilate and transmit. Amongst others, the depiction of the female body as a tool in the hands of the community for mere reproductive purposes, and, accordingly, the rejection of female sexuality were deeplyrooted within the patriarchal Chicano community. The situation of the Chicana, hence, becomes the symbol of a double kind of colonization: on the one hand, she lives in a state of cultural, linguistic and social colonization within the North American society, just as her male counterpart does, and on the other hand, she experiences an internal kind of personal colonization, provoked by the strong patriarchal rules and understanding of male-female relationships that is prevalent within her own community. As a consequence of this second type 
of colonization, the body, which had long been controlled by the male community in an attempt to maintain the prevailing social order, becomes the symbol of the oppression of the Chicana's sexual identity. The task of Chicana writers is that of reinterpreting the myths and taboos that had been related to it for years, as well as to redescribe it as the outer, public image of the woman. Freeing the body from the chains of the colonizer symbolizes the trespassing of a deeply-rooted barrier, for, as Ana Castillo explains: "We maintained the business of our bodies behind closed doors. (...) We had been taught not to name those feelings and fantasies, much less affirm their meanings" (1995: 122). As a consequence, its conscious acceptance and enjoyment becomes a turning point in the process of the creation and revision of the woman's identity:

For Chicana writers, it has been extraordinarily liberating to write about the body, and many of them are engaged in a battle of sexual politics of naming and representing the female power and the female space of the body. It is a sexual naming that comes from the female experience itself, not from outside objectified experience, and, of course, in Chicana writing, it comes from the specificity of Chicana sexual politics, however that may manifest itself. (Rebolledo, 1995: 196)

The moment when the body is accepted as a source of knowledge of one's self is an important matter of consideration in Terri de la Peña's novel, who portrays women who are, at the time of being depicted, struggling to make their sexuality, lesbian in most of the cases, known and acknowledged before the rest of the community. The fact of making lesbian women the protagonists of her works, makes de la Peña a writer who breaks the rules of "righteousness, decency and morality", which the Chicano community, strongly influenced by the Catholic Church, regards as the stronghold of the value system in which the stability of the community relies on. Accordingly, as Gloria Anzaldúa explains,

For the lesbian of color, the ultimate rebellion she can make against her native culture is through her sexual behaviour. She goes against two prohibitions: sexuality and homosexuality. (1987:19)

Margins, published in 1993 , chronicles the story of Verónica, a young Chicana lesbian who has lost her lover, Joanna, in a car accident, and consequently feels as if an essential part of her ego had disappeared. Her identity shuttered and fragmented, she remains trapped within her own silence and the "reality" she had constructed with her lover. Thus, she chooses to be in this "comfortable" position of transparency in the eyes of her community, reminiscent of Leela Ghandi's idea: "The 'third-world woman' is arguably housed in an 'identifiable margin"" (Ghandi 1998:84). As a consequence, she experiences a strong sense of displacement from her community, and is afraid of the group's reaction should she dare to make her true identity public. This situation places her in a state of self-denial and insecurity, described by Bonnie Zimmerman in the following terms:

This problem of definition is exacerbated by the problem of silence. One of the most pervasive themes in lesbian criticism is that woman-identified writers, silenced by a homophobic and misogynistic society, have been forced to adopt coded and obscure language and internal censorship. (1981: 207) 
Verónica's reality at the outset of the novel may well be considered analogous to the origins of the story of the Chicanas. The silence imposed upon these women kept them from breaking down the barriers that denied them their own voice, and which forced them to assimilate and perpetuate the colonized depictions of their identities. As the novel, together with the main character's renegotiation and valorisation of her identity develops, writing becomes the axis of this (r)evolutionary process. Verónica attends university, and one of her Chicana professors asks her to write some stories for the class. She explains,

One of them involves sexual experimentation between Chicana teenagers- obviously, it's autobiographical. If Zamora wants Chicana stories from me, that what she's getting. Anyhow, besides Cherrie Moraga and Gloria Anzaldúa, who else writes about Chicana lesbians nowadays? (de la Peña, 1993: 271)

Initially, writing becomes an imposed duty for her, but later on, she will regard it as something necessary and extremely valid for the acceptance and expression of her new identity, for as Gloria Anzaldúa points out in This Bridge Called My Back, "to write is to confront one's demons, look them in the face and live to write about them" ( Moraga \& Anzaldúa, 1981: 171). The fact of making reference to real Chicana writers, just as observed in the above quotation, provides the scene with an immense realism. Verónica's story, as portrayed in the novel, may well represent any Chicana lesbian's story, whose fight is aimed towards the community's acceptance of her "difference". Thus, it becomes real and authentic. As explained by Rosaura Sánchez, when analysing Alvina Quintana's Home Girls:

The premise is that Chicana writers, as would-be ethnographers, deconstruct their own experience through self-analysis and self-representation and, in that way, ostensibly "eliminate the possibility of outside misinterpretation of cultural symbolic systems", enabling the marginal "to become the subjects of their own discourse" (1997: 352)

By means of depicting this kind of character, de la Peña invites the readers to follow her steps, deproblematizing their situation courageously. This attempt to make Chicana lesbian vindications public, would make them heard and be received by the rest of the community because " in their case, sexual identity seems to follow ethnic, class and gender identity" (Castillo, 1991: 40). The notion of creating community and a sense of belonging are thus acquired by the writing/reading process as observed in the case of Verónica. Chronicling his/ her own story, the writer creates an intimate bond with the reader who experiences the same needs and identifies him/herself with this writer. As a consequence, as explained by Tey Diana Rebolledo,

Many stories written by Chicanas chronicle the world in which the female hero's expectations conflict with the dictates of the surrounding society. Chicana heroes desire freedom to be themselves, in all of their abilities and aspects, a freedom often denied by a culture that would have them to strict norms of behaviour for young women. (1995: 111)

Verónica's stories acquire a strong autobiographical tone from the beginning. The fact of creating a fictitious character that adopts her personal characteristics and experiences the same situation, helps her show her truth in a freer way. Writing becomes the ambivalent 
process that symbolizes the means of escape through which she discovers her secret and rids herself of its oppression. Moreover, it facilitates the proclaiming of her identity, for she is fully aware and conscious of the fact that this "different" identity will not be easily accepted by certain members of her community. Furthermore, presenting an invented character for this task, she tones down the difficult situation she finds herself in and disguises her story in the eyes of the community. The analogy among the Chicana writers and Verónica's story is once again present, for they, just like the novel's main character, create characters similar to Verónica to transmit their message, which, in a way reminiscent of de la Peña's protagonist's, has a strong component of "gender-bound" vindication. Even though Verónica is convinced that the fact of belonging to an ethnic minority distinguishes her from women like Siena, a white lover that she has after Joana's death, her main concern has to do with the fact of being a woman, and a lesbian.

Verónica felt herself blush again. "Let's just say I'm starting to head in that direction. My work has a Chicana slant, but the lesbian subtleties are surfacing" (de la Peña, 1993: 101)

The Chicana writers also opt for this direction in their works and use their novels as models for the rest of the women. Furthermore, their novels are regarded as a means of inciting the readers to take the path the protagonist has taken, the one of creating stories which help them vindicate their rights and proclaim aloud their true identity. Writing is considered a valid procedure of publication of the identity, and it is for this reason that many Chicana writers chronicle stories in which women narrate other women's stories in a cyclical way. De la Peña's work, thus, belongs to the genre of the Künstlerromane, in which protagonists that are in conflict with the idea of having to show their real selves, choose to transmit it by means of creative devices, a fact that Annie O. Eysturoy defines in the following terms:

The intimate connection between the quest for self-development, a sine qua non of the female Bildungsroman, and the concept of creativity as a catalyst for self-discovery is the basic theme of many female Künstlerromane. (1996: 21)

Both the writer of the novel and her protagonist adopt the creative process as the most appropriate so as to express the outcome of the search for their identity. It represents a way of liberating oneself and opening up to the rest of the community, and in a defensive way, protecting themselves behind the shelter of a fictitious character, who vindicates all that they want to fight for, and may keep them safe from a possible rejection by the community. Writing about her own experiences supports ideas such as Barbara Cameron's, who calls upon third world gay people to confront their oppression:

It is of particular importance to us as third world gay people to begin a serious interchange of sharing and educating ourselves about each other. We not only must struggle with the racism and homophobia of straight white America, but must often struggle with the homophobia that exists within our third world communities. Being third world doesn't always connote a political awareness or activism. (1981: 50)

The Chicana writer reveals her experiences from the point of view of the narrator, from a perspective that comes from closeness and knowledge of the situation. She thus recovers 
the narrative voice that she had been denied by her male counterparts for the maintenance of the patriarchal structure of the community. Verónica abandons the "margins" of her story to take a central position in the development of her new life, in which she fights to renegotiate her space within her community as well as to re-educate its members into a more tolerant, integrative understanding of life.

\section{REFERENCES}

Anzaldúa, G. 1987. Borderlands: La Frontera. The New Mestiza. San Francisco: Aunt Lute Books.

Cameron, B. 1981. “Gee, you don't seem like an Indian from the reservation”. This Bridge Called My Back. Ed. Ch. Moraga and G. Anzaldría. 46-52

Castillo, A. 1991. "La Macha: Towards a beautiful whole self”. Chicana Lesbians. The Girls Our Mothers Warned Us About. Ed. C. Trujillo. Berkeley: Third Woman Press. 24-48.

1995. Massacre of the Dreamers. Essays on Xicanisma. New York: Plume, Penguin Books.

de la Peña, Terri. 1993. Margins. Seattle, WA: Seal Press,.

Eysturoy, A. O. 1996. Daughters of Self-Creation. The Contemporary Chicana Novel. Albuquerque: University of New Mexico Press.

Gandhi, L. 1998. Postcolonial Theory. A Critical Introduction. Edinburgh: Edinburgh University Press.

Henderson, M., ed. 1995. Borders, Boundaries and Frames. Cultural Criticism and Cultural Studies. New York: Routledge.

Moraga, Ch. and G. Anzaldúa, eds. 1981. This Bridge Called My Back. Writings by Radical Women of Color. New York: Kitchen Table Press.

Ramos Escandón, C. 1989. “Alternative sources to women's history: Literature”. Between Borders: Essays on Mexican-Chicano History. Ed. A. del Castillo. Los Angeles: Floricanto Press. 201-212.

Rebolledo, T. D. 1995. Women Singing in the Snow. A Cultural Analysis of Chicana Literature. Tucson: University of Arizona Press.

Sánchez, R. 1997. "Reconstructind Chicana gender identity". American Literary History, vol. XIX, summer: 350-362.

Yarbro-Bejarano, Y. 1988. "Chicana literature. From a Chicana feminist perspective". Chicana Creativity and Criticism. Charting New Frontiers in American Literature. Ed. M. Herrera-Sobek. Houston, TX: Arte Público Press. 139-145.

Zimmerman, B. 1981. "What has never been. An overview of lesbian literary criticism”. The New Feminist Criticism. Ed. E. Showalter. London: Virago. 200224. 